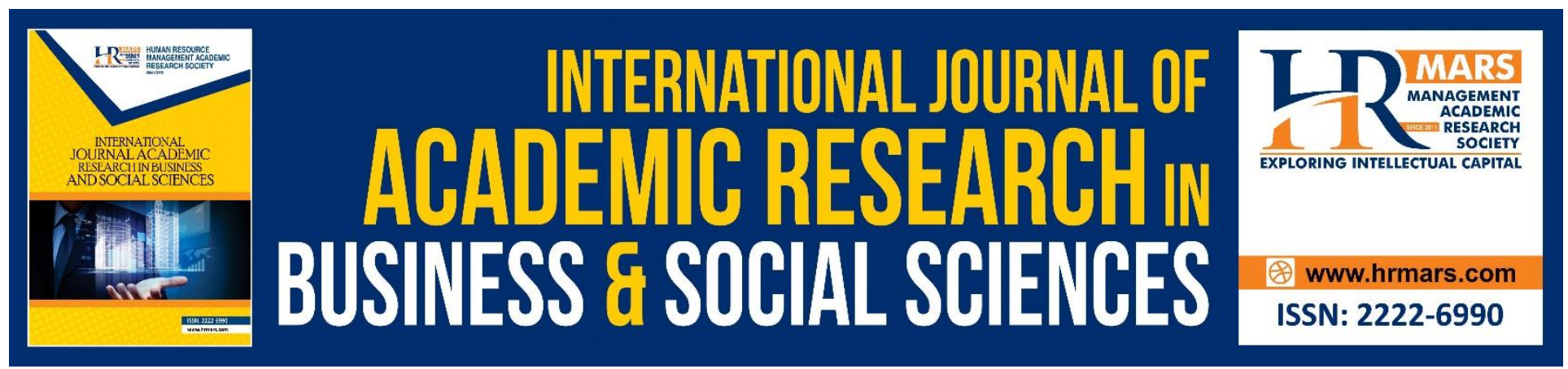

\title{
Destination Image towards Revisit Intention to Natural Protected Areas in Sarawak: A Study of Functional Characteristics
}

Jun-Zhou, Thong, Jia-Lie, Ching, Ying-Sin, Chin

To Link this Article: http://dx.doi.org/10.6007/IJARBSS/v10-i9/7631

DOI:10.6007/IJARBSS/v10-i9/7631

Received: 09 June 2020, Revised: 16 July 2020, Accepted: 20 August 2020

Published Online: 19 September 2020

In-Text Citation: (Thong, Ching, Chin, 2020)

To Cite this Article: Thong, J. Z., Ching, J. L., Chin, Y. S. (2020). Destination Image towards Revisit Intention to Natural Protected Areas in Sarawak: A Study of Functional Characteristics. International Journal of Academic Research in Business and Social Sciences. 10(9), 272-287.

Copyright: (C) 2020 The Author(s)

Published by Human Resource Management Academic Research Society (www.hrmars.com)

This article is published under the Creative Commons Attribution (CC BY 4.0) license. Anyone may reproduce, distribute, translate and create derivative works of this article (for both commercial and non-commercial purposes), subject to full attribution to the original publication and authors. The full terms of this license may be seen at: http://creativecommons.org/licences/by/4.0/legalcode

Vol. 10, No. 9, 2020, Pg. 272 - 287

http://hrmars.com/index.php/pages/detail/IJARBSS

JOURNAL HOMEPAGE

Full Terms \& Conditions of access and use can be found at http://hrmars.com/index.php/pages/detail/publication-ethics 


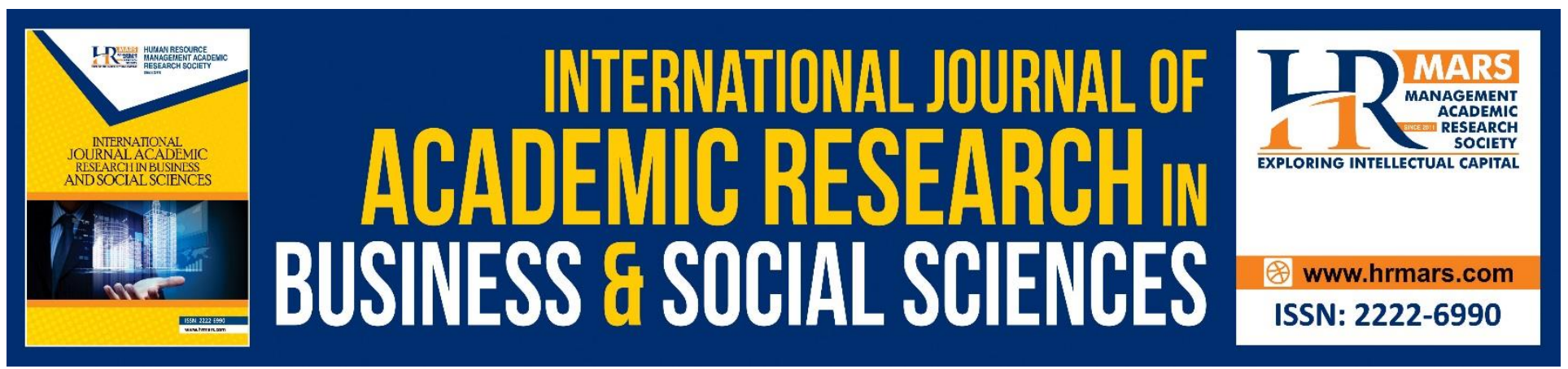

\title{
Destination Image towards Revisit Intention to Natural Protected Areas in Sarawak: A Study of Functional Characteristics
}

\author{
Jun-Zhou, Thong, Jia-Lie, Ching, Ying-Sin, Chin \\ Faculty of Economics and Business, Universiti Malaysia Sarawak, 94300 Kota Samarahan, Sarawak, \\ Malaysia. \\ Email: junzhou_9@hotmail.com,cjlcarrie@gmail.com,cynthiachin95@gmail.com
}

\begin{abstract}
Ecotourism is one of the major motives in tourism development through this advancing digitalized world. Moreover, the government is looking forward to seeing an opportunity to enhance attractiveness of ecotourism creation through the Visit Truly Asia Malaysia 2020 initiative. Furthermore, the sustainability of destination image should be established in a way that significantly increases the revisit intention of tourists. This study is to examine the relationship between the functional characteristics of destination image and revisit intention, namely, natural and historical attractions, entertainment and tourism activities, and tourism infrastructure as well as price and value. A total of 283 respondents comprising tourists both local and foreign tourists visited Gunung Mulu National Park, Gunung Gading National Park, Bako National Park, Kubah National Park and Niah National Park in Sarawak, Malaysia took part voluntarily in this study. In the evalutation of the developed model, WarpPLS 7.0 was implemented based on path modelling and bootstrapping to obtain the estimation of standard error and p-values. Interestingly, the findings revealed that only price and value had a significant positive impact on tourists' revisit intention, whereas no significant impact found among natural and historical attractions, entertainment and tourism activities, and tourism infrastructure. Implications of these results will be further discussed.
\end{abstract}

Keywords: Destination Image, Functional Characteristics, Revisit Intention, Ecotourism, National Parks.

\section{Introduction}

The evolution of digital advancement has shown that ecotourism has become the preferred way for people to rewire with nature and seeking for authentic natural experiences (Forbes, 2017). Ecotourism is serving for holiday-makers traveling to an uninterrupted environment with natural manifestations to enjoy breath-taking scenery, flora and fauna, along with any historical and contemporary cultural resources that exist in those natural areas (e.g. national parks) (Chiutsi, Mukoroverwa, Karigambe, \& Mudzengi, 2011; Coria \& Calfucura, 2012; Mondino \& Beery, 2018). 
Moreover, a study revealed that tourists have a higher preference in ecotourism as they consider the natural environment to be the priority of the choice of destination in travel decisions (Center for Responsible Travel, 2017). Based on the fact, destination management and development play a crucial role in developing favourable destination image in sustaining the growth of tourism destinations (Whang, Yong, \& Ko, 2016; Loi, So, Lo, \& Fong, 2017; Islam, Hossain \& Noor, 2017; Dean, Surhartanto, \& Kusdibyo, 2019). Correspondingly, Malaysia's Ministry of Tourism, Arts and Culture (MTAC) has intensified its efforts to concentrate on ecotourism whereby Visit Malaysia 2020 initiative is targeting a total of 30 million international tourists and a total of RM100 billion in tourist receipts to the country (Tourism Malaysia, 2019).

According to the report of Ministry of Tourism, Arts and Culture (MTAC), Sarawak, Malaysia has shown an increment of the growth rate of $5.22 \%$ in visitor arrivals. Thus, ecotourism also embraces a range of tourism management challenges and issues. Nevertheless, inactive tourism management plan leading to over-tourism which is overcrowding of destinations particularly in national parks (Center for Responsible Travel, 2018). As a side effect, due to the decline in the arrivals of tourists, the quality of the visitor experience is dramatically reduced and affected on the national park revenues. Besides that, ineffective tourism management also causes environmental degradation of the nature reserve, such as noise, air, and water pollution (Nianyong \& Zhuge, 2001; Eagles, 2002; Anup, 2016).

This study was conducted in the five selected national parks which located in Sarawak, Malaysia namely Gunung Mulu National Park, Gunung Gading National Park, Bako National Park, Kubah National Park and Niah National Park. Every year these National Park received a large number of visitations from both local and foreign tourists mainly nature lovers. The richness and universe of ecotourism attraction plays a vital role in attracting visitors to the national park. Therefore, the destination image has become necessary and diverse for the positioning of tourism products in order to influence the choice of destination and revisit intention of tourists (Lopes, 2011; Lo, Songan, \& Mohamad, 2013; Saliva, Anjos, \& Pereira, 2018).

\section{Study Objectives}

The aim of this study is to analyse the functional characteristics of destination picture, including natural and historical attractions, entertainment and tourism activities, and tourism infrastructure, along with price and value for intention to revisit from the perspectives of tourists. The objectives of the present study are specified as follows:

- To examine the relationship between natural, historical attractions and tourists' revisit intention.

- To explore the relationship between entertainment, tourism activities and tourists' revisit intention.

- To examine the relationship between tourism infrastructure and tourists' revisit intention.

- To examine the relationship between price, value and tourists' revisit intention. 
INTERNATIONAL JOURNAL OF ACADEMIC RESEARCH IN BUSINESS AND SOCIAL SCIENCES Vol. 10, No. 9, 2020, E-ISSN: 2222-6990 @ 2020 HRMARS

\section{Conceptual Background and Hypotheses Development Theory of Planned Behavior}

Theory of planned behaviour (TPB) is one of the most prominent and influential theory for studying the revisit intention of tourists as well as for understanding and predicting the behavioural intentions of individuals (Ajzen, 2002; Chang, 2013; Huang, Chang \& Backman, 2018). The TPB concentrated on intention of tourists to visit or revisit to understand the motivation for travel and behaviour of tourists (Li, Cai, Lehto, \& Huang, 2010). As an improvement from reasoned action theory (TRA), Ajzen (1991, p. 188) described theory of planned behaviour theory, as the intentions of a person are affected by attitudes, subjective norms and perceived behaviour control. Attitudes refers to a favourable or unfavourable assessment of the person or analysis and evaluation of the behaviour; subjective norms refer to behaviour is considered to be perceived as social pressure to accomplish or not to accomplish individual behaviour; and perceived behavioural control is described as a perception of the person's ability to perform behaviour.

TPB has been widely adopted by many scholars to predict and understand individual behavioural intentions in a wide range of leisure settings. Recent research (Choo, Ahn, \& Petrick, 2016; Japutra, Loureiro, Molinillo, \& Ekinci, 2019) have shown that the behavioural intentions of tourists play a key role in influencing their travel experience and choice of destination. The theory has revealed that the commitment of tourists to a destination that influences the intention to purchase and revisit (Sarkar, 2014; Boujbel \& d'Astous, 2015) which indicated specific behaviours such as favourable or unfavourable, positive or negative, and willingness or unwillingness (Lee, Hsu \& Han, 2010; Vesci \& Botti, 2019). Therefore, the present study apparently applied the theory of planned behaviour in the research framework by linking the destination image dimensions to revisit intention.

\section{Revisit Intention}

Revisit intention is described as tourists visit the destination repeatedly and are likely to recommend and share positive recommendations with others (Som \& Badarneh, 2011; Chin, Law, Lo, \& Ramayah, 2018). Previous researches (Chi \& Qu, 2008; Chen \& Chen, 2010; Qu, Kim, \& Imm, 2011; Sadat \& Chang, 2016; Stylidis, Shani, \& Belhassen, 2017) suggested that the intention to revisit as tourist loyalty toward a destination and plan to return the same destination. Apart from this, destination image also plays an important character to influence the travel decision and tourists' intention to revisit the same destination in future (Cohen, Prayag, \& Moital, 2014; Isaac \& Eid, 2018). On the other hand, current study (Cui, Lee, Lee \& Kim, 2019) also claimed that revisit intention is a key element of tourist destination loyalty in shaping their satisfaction and attitude, which means that tourists have a direct effect on the destination's attachment.

\section{Functional Characteristics}

Functional characteristics are characterized as tangible aspects of the image of destination that can be directly observed and measured by physical attributes (Echtner \& Ritchie, 1993; Echtner \& Ritchie, 2003; Mohamad \& Ghani, 2014; Trung \& Khalifa, 2019). It includes natural and historical attractions, entertainment and tourism activities, tourism infrastructure, price and value (Echtner \& Ritchie, 1991; Echtner \& Ritchie, 2003). 
INTERNATIONAL JOURNAL OF ACADEMIC RESEARCH IN BUSINESS AND SOCIAL SCIENCES Vol. 10, No. 9, 2020, E-ISSN: 2222-6990 @ 2020 HRMARS

\section{Natural and Historical Attractions}

Natural and historical attractions relate to the core resources and attractors as well as the authenticity of tangible destination which are considered elements of destination image (Bonn, Cho, Lee \& Kim, 2016), such as natural scenery, climate, flora and fauna, cultures, historical sites and works of art. Previous studies (Hernández-Lobato, Solis-Radilla, Moliner-Tena, \& Sánchez-García, 2006; Packer, Ritchie \& Ballantyne, 2011; Xu, Cui \& Ballantyne 2013) highlighted that natural attraction is one of the major factors that affect the behavioral intention of tourists towards the destinations. Moreover, positive tangible destination image attributes (historical attractions) have a major effect on the decision-making of tourists to revisit a destination (Tasci \& Gartner, 2007; Kim, Hallab, \& Kim, 2012) which correlated to destination loyalty to ensure the longevity of the destination (Baniya, Ghimire, \& Phuyal, 2017). Furthermore, tourists' perception of natural and historical attractions might create a memorable travel experience in order to influence revisit intention (Zhang, Wu, \& Buhalis, 2018). The following hypothesis is developed based on existing research:

H1: Natural and historical attractions are positively related to revisit intention.

\section{Entertainment and Tourism Activities}

Entertainment and tourism activities are referred to as a leisure destination which provides tourists with fun, pleasure, pleasure and excitement travel experiences including street entertainment, nightlife, dance performances, cultural festivals, shopping and shows (Chi \& Qu, 2008; Luo \& Lam, 2017). A study by Lertputtarak (2012) showed that entertainment and tourism activities have a positive relationship on revisit intention to manipulate the perception of tourists and to improve the visit experience of tourists to the tourism destination. Subsequently, entertainment and tourism activities are increasingly shaping the behavioural intention of tourists in making visitation decisions in order to create unforgettable experiences (Harun, Obong, Kassim, \& Lily, 2018; Wu, Li \& Li, 2018; Zhang et al., 2018). Thus, entertainment and tourism activities are a marketing resource for retaining and attracting tourists to return or repeat as well as to recommend the destination to others (Yelkur, 2000). According to the above research discussion, the subsequent hypotheses are formed:

$\mathrm{H}$ 2: Entertainment and tourism activities are positively related to revisit intention.

\section{Tourism Infrastructure}

Tourism infrastructure refers to the ease of a tourism destination's transport facilities and basic services (Mo, Howard, \& Havitz, 1993). Murphy, Pritchard \& Smith (2000) highlighted the importance of infrastructure facilities in contributing to the efficiency of destination growth and tourists' revisit purpose (Nunkoo \& Seetanah \&, 2018). Moreira and lao (2014) further suggested that tourism infrastructure is one of the important elements for attracting tourists to the destination. Additionally, good tourism facilities improve the accessibility and convenience of tourists to a particular tourism destination (Su \& Wall, 2009), thereby creating a desirable popular tourism destination image (Grytsiuk \& HGryciuk, 2017). Hence, tourism infrastructure quality is an important attribute to attract tourists to the destination (Mazilu \& Stancioiu, 2009; Moric, 2013; Jovanovic \& Ilic, 2016; Mandić, Mrnjavac, \& Kordić, 2018). According to the above research discussion, the subsequent hypotheses are formed:

H3: Tourism infrastructure is positively related to revisit intention. 


\section{Price and Value}

Price and value refer to what tourists pay for their travel, including the quality of services and products which correspond to the actual value (Ngoc \& Trinh, 2015). The acceptable price and value are the fundamental components for manipulating tourist satisfaction to assess tourist's revisit intention towards destination (Qu, 1997; Lee, 2004). In fact, Kim, Ng, and Kim (2009) suggested that price and value are significant determinants of the revisit intention leading to increase in local economic benefits (e.g. sales, profit). Dwyer and Kim (2003) have emphasized that the price of goods or services should be equivalent with the value to maximize tourists ' satisfaction with the standard of service. Moreover, price and value have an impact on the satisfaction of tourists and revisit intention related to the perception of tourists on the assessment of the experience gained from the trip (Murphy et al., 2000; Yan, Wang, \& Chau, 2015). Consequently, price and value as a predictor of destination in shaping the intention of tourists to visit again (Long \& Nguyen, 2018). The following hypothesis is developed based on existing research:

H4: Price and value are positively related to revisit intention.

\section{Methodology}

The research population comprises both local and foreign tourists visit to Sarawak, Malaysia's Top 5 National Park as reported by TripAdvisor in 2019. The non-probability sampling method, purposive sampling method has been used in the selection of respondents in which respondents aged 16 and above would take the opportunity to be chosen as one of the respondents to this study. Nonprobability sampling is a technique used to select the sample based on personal judgment and not on the size of the population (Zikmund, Babin, Carr, \& Griffin, 2010; Sekaran \& Bougie, 2013). In this study, the quantitative approach to survey questionnaires has been used as a survey tool for data collection. The questionnaire consisted of 57 items adapted from the previous study and adapted to the Malaysian context. The respondents are tourists who are visiting or have visited Gunung Gading National Park, Gunung Mulu National Park, Bako National Park, Kubah National Park and Niah National Park. A total of 300 sets of questionnaires were collected and used for statistical analysis using the convenience sampling technique.

First, the data went through a series of preliminary analyses via the Social Sciences Statistical Package 26.0 (SPSS). A total of 17 questionnaires have been discarded due to incomplete data. WarpPLS 7.0 (Kock, 2017) was then used with 283 data sets to evaluate the research model as shown in Figure 1. The data first went through the measurement model and then the structural model in the PLS analysis. The measurement model includes an assessment of the reliability, convergent and discriminant validity of the measure. After that, bootstrapping was performed to test the hypothesized relationship between the constructs. 
INTERNATIONAL JOURNAL OF ACADEMIC RESEARCH IN BUSINESS AND SOCIAL SCIENCES Vol. 10, No. 9, 2020, E-ISSN: 2222-6990 @ 2020 HRMARS

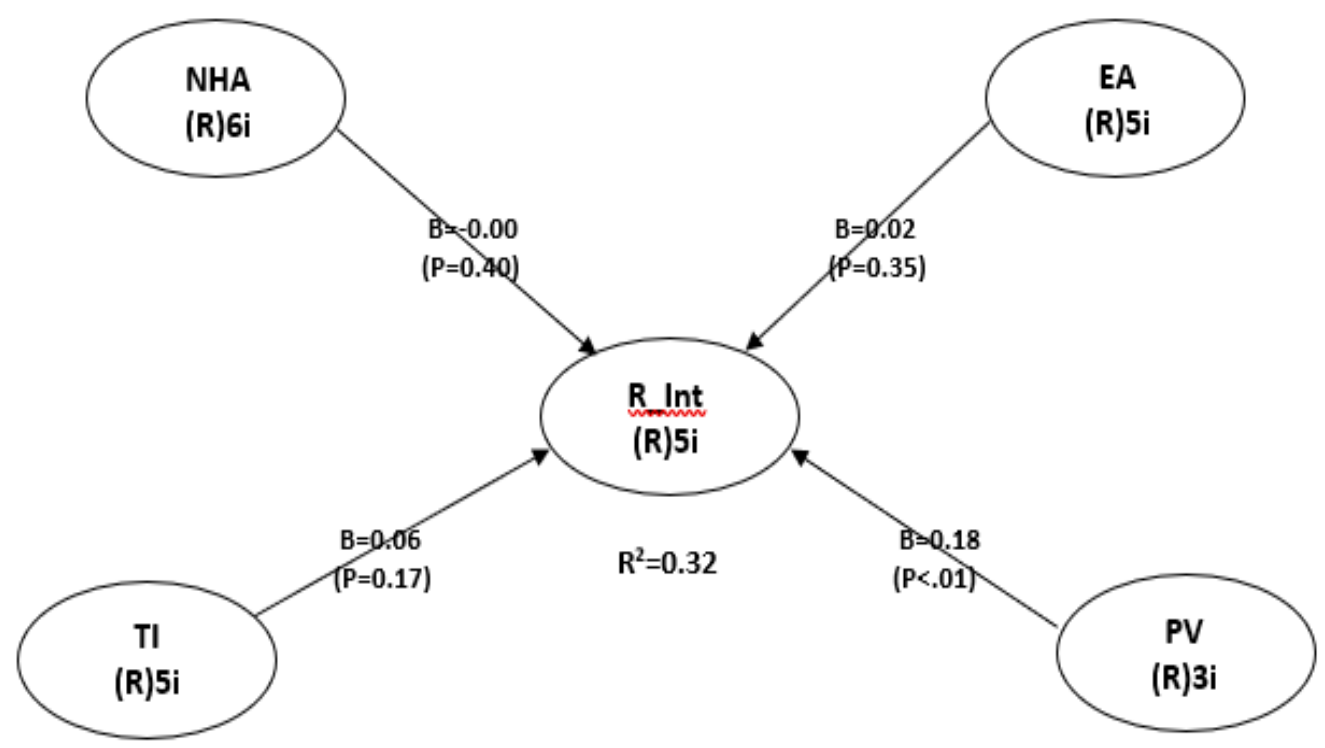

Figure 1: Research Model with path coefficients and p-values

\section{Results and Discussion}

WarpPLS 7.0 has been applied to evaluate the research model as proposed in this report. A two-step approach was carried out, where the measuring model is evaluated in the first step, involving the assessment of the construct's reliability and validity (Hair, Hult, \& Ringle, 2017). The evaluation of the structural model was conducted in the second stage, enabling the assessment of proposed relationships between the constructs.

\section{Assessment of the Measurement Model}

The reliability, convergent and discriminating validity of the measures were tested by using the confirmatory factor analysis (CFA) approach. Table 1 abstained from the loadings with thresholds of 0.5 and above to ensure internal consistency (Bagozzi, Yi, \& Philipps, 1991). The composite reliability (CR) values, as suggested by Chin (2010), should meet the minimum cut-off point of 0.7 to declare validity. The extracted mean variance (AVE) values should meet the minimum criteria of 0.50 (Fornell \& Larcker, 1981). As a result, the CR and AVE values respectively met the minimum criteria. In order to test the reliability and internal consistency of the instrument, the alpha values of Cronbach were also adopted (Cronbach, 1951), and the results indicated that the alpha values of the Cronbach for cultural heritage attraction, tourism infrastructure, range of activities and competitiveness of destinations were identified at a good level, whereas the value of natural resources was considered acceptable As Nunally and Bernstein (1994) suggest, the value of 0.60 indicates poor, $0.61-0.79$ indicates acceptable, and above 0.80 indicates good level respectively. Discriminant validity of the measures is shown in Table 2, referring to Fornell and Larcker's (1981) criterion, the AVE value was squarely rooted and testified against the inter-correlation of the construct with other constructs in the research model and all the values noted to be higher than the correlation of each construct (Chin, 2010). The measurement model was therefore appropriate, and proof is given in terms of reliability, convergent and discriminant validity. In addition, the determination coefficient $\left(R^{2}\right)$ for the competitiveness of the destination was 0.325 , which explained 32.5 per cent of the construction. The 
INTERNATIONAL JOURNAL OF ACADEMIC RESEARCH IN BUSINESS AND SOCIAL SCIENCES Vol. 10, No. 9, 2020, E-ISSN: 2222-6990 @ 2020 HRMARS

$\left(R^{2}\right)$ was above the minimum indication suggested by Cohen (1998) that is slightly above the $R^{2}{ }_{-} 0.19$ value.

\begin{tabular}{|l|c|c|c|c|c|c|c|}
\hline \multicolumn{1}{|c|}{ Construct } & $\begin{array}{c}\text { No of } \\
\text { Items }\end{array}$ & $\begin{array}{c}\text { Items } \\
\text { Deleted }\end{array}$ & Items & Loadings & CR & $\begin{array}{c}\text { Cronbach's } \\
\text { Alpha }\end{array}$ & AVE \\
\hline Natural and & 6 & 0 & NHA_1 & 0.802 & 0.950 & 0.936 & 0.759 \\
Historical & & & NHA_2 & 0.863 & & & \\
Attraction & & & NHA_3 & 0.901 & & & \\
& & & NHA_4 & 0.882 & & & \\
& & & NHA_5 & 0.879 & & & \\
\hline Entertainment & 5 & 0 & EA__6 & 0.897 & & & 0.662 \\
and Tourism & & & EA_2 & 0.774 & & & \\
activities & & & EA_3 & 0.853 & & & \\
& & & EA_4 & 0.899 & & & \\
\hline Price and Value & 3 & 1 & EA_5 & 0.888 & & & \\
& & & PV_1 & 0.723 & 0.809 & 0.746 & 0.586 \\
& & & PV_2 & 0.782 & & & \\
\hline Tourism & 5 & 3 & TI_1 & 0.789 & & & \\
Infrastructure & & & TI_2 & 0.820 & 0.909 & 0.874 & 0.666 \\
& & & TI_3 & 0.837 & & & \\
& & & TI_4 & 0.822 & & & \\
& & & TI_5 & 0.774 & & & \\
\hline Revisit & 5 & 0 & RI_1 & 0.702 & 0.840 & 0.761 & 0.513 \\
Intention & & & RI_2 & 0.643 & & & \\
& & & RI_3 & 0.784 & & & \\
& & & RI_4 & 0.678 & & & \\
& & & RI_5 & 0.765 & & & \\
\hline
\end{tabular}

Table 1: Summary of Construct Reliability and Validity

\begin{tabular}{|l|c|c|c|c|c|}
\hline & $\begin{array}{c}\text { Natural and } \\
\text { Historical } \\
\text { Attraction }\end{array}$ & $\begin{array}{c}\text { Entertainment } \\
\text { and Tourism } \\
\text { activities }\end{array}$ & $\begin{array}{c}\text { Price and } \\
\text { Value }\end{array}$ & $\begin{array}{c}\text { Tourism } \\
\text { Infrastructure }\end{array}$ & $\begin{array}{c}\text { Revisit } \\
\text { Intention }\end{array}$ \\
\hline $\begin{array}{l}\text { Natural and Historical } \\
\text { Attraction }\end{array}$ & $\mathbf{0 . 8 7 1}$ & 0.005 & $\mathbf{0 . 8 1 4}$ & & \\
\hline $\begin{array}{l}\text { Entertainment and } \\
\text { Tourism activities }\end{array}$ & 0.342 & 0.104 & $\mathbf{0 . 7 6 5}$ & & \\
\hline Price and Value & 0.281 & 0.059 & 0.363 & $\mathbf{0 . 8 1 6}$ & \\
\hline $\begin{array}{l}\text { Tourism } \\
\text { Infrastructure }\end{array}$ & 0.490 & 0.078 & 0.645 & 0.423 & $\mathbf{0 . 7 1 7}$ \\
\hline Revisit Intention & &
\end{tabular}

Table 2: Discriminant Validity of Constructs of HTMT of Measurement Model 
INTERNATIONAL JOURNAL OF ACADEMIC RESEARCH IN BUSINESS AND SOCIAL SCIENCES Vol. 10, No. 9, 2020, E-ISSN: 2222-6990 @ 2020 HRMARS

\section{Assessment of the Structural Model}

Then the results of the testing of hypotheses are reported in Table 3. As a rule of thumb for the testing of one-tailed hypotheses, $p$-value must be lower than 0.01 or 0.05 . The statistical findings showed that one of the hypotheses tested for the direct relationship were accepted. Price and value have been found to have significant positive relationship with destination image from the perspective of both domestic and international visitors. Interestingly, there was no support for the other three hypotheses, which are hypothesised with the significant relationship between latent variables, namely natural and historical attraction, entertainment and tourism activities, and tourism infrastructure as shown by the findings that they were not important. In addition, the values of the inflation factor of variation (VIF) were also acquired to assess the multicollinearity problem among the constructs. The results suggested that all the VIF values did not surpass 10 , according to Bock, Zmud, Kim, \& Lee (2005), therefore it is verified that there is no multicollinearity problem among the constructs.

\begin{tabular}{|c|l|c|c|c|c|c|}
\hline Hypothesis & \multicolumn{1}{|c|}{ Relationship } & $\begin{array}{c}\text { Standard } \\
\text { Beta }\end{array}$ & $\begin{array}{c}\text { Standard } \\
\text { Error }\end{array}$ & p-value & Decision & $\mathbf{f}^{\mathbf{2}}$ \\
\hline H1 & $\begin{array}{l}\text { Attraction >> Revisit } \\
\text { Intention }\end{array}$ & 0.002 & 0.059 & 0.487 & $\begin{array}{c}\text { Not } \\
\text { Supported }\end{array}$ & 0.007 \\
\hline H2 & $\begin{array}{l}\text { Entertainment and } \\
\text { Tourism Activities }> \\
\text { Revisit Intention }\end{array}$ & -0.022 & 0.059 & 0.353 & $\begin{array}{c}\text { Not } \\
\text { Supported }\end{array}$ & 0.003 \\
\hline H3 & $\begin{array}{l}\text { Price and Value >> } \\
\text { Revisit Intention }\end{array}$ & 0.157 & 0.058 & $0.004^{* *}$ & Supported & 0.064 \\
\hline H4 & $\begin{array}{l}\text { Infrastructure >> } \\
\text { Revisit Intention }\end{array}$ & 0.057 & 0.059 & 0.169 & $\begin{array}{c}\text { Not } \\
\text { Supported }\end{array}$ & 0.022 \\
\hline
\end{tabular}

Note: ${ }^{*} p<0.05, * * p<0.01$

Table 3: Summary of Path Coefficients and Hypothesis Testing The resulting study for hypothesis 3 showed that price and value contribute positively to tourists' intention to revisit in the context of Gunung Gading National Park, Gunung Mulu National Park, Bako National Park, Kubah National Park, and Niah National Park. As the result revealed, price and value in these natural protected areas can be concluded as a determinant of tourists' revisit intentions to ecotourism destinations. Price and value are of the basic criteria when visitors are making decisions to travel, while acting as a source of attraction for tourists (Crouch \& Ritchie, 1999; Lane, 2009). This finding is congruent with past study where price and value of a destination have positive impact on revisit intention (Murphy et al., 2000; Yan et al., 2015). It has been suggested that good price and value destinations are capable of raising the likelihood of tourist purchasing behavior of tourism products and repeated visits to the same destination as price and value insight reflect the actual experience of tourists in the tourism destination (Petrick, 2004; Liu \& Lee, 2016; Long \& Nguyen. 2018). The plausible reason could be due to the fact that, despite its long distance from the city, these national parks can fulfil the daily necessity of tourists fairly and equitably. A positive tourism experience is linked to fulfilling the satisfaction of the tourists and their lives (Jung, 2015; Shen, 2016). 
The results showed that three of the other destination picture elements (e.g.: natural and historical attraction, entertainment and tourism activities, and tourism infrastructure) had no important connexion with the revisiting intentions of tourists. The statistical finding from hypothesis 1 has shown that the appeal of natural and historical has no major effect on the purpose of revisiting. Interestingly, this finding contradicts past studies that suggest that the appeal of natural and historical has a positive influence on tourists' intention to revisit (Khuong \& Nguyen, 2017; Karim, Setarnawat, \& Viriyasuebphong, 2019). According to the feedback given by tourists during the interview, local as well as international tourists consider that harm to natural and historical sites such as beach garbage and degradation of heritage trails reduces their behavioural purpose in these natural protected areas, namely Gunung Gading National Park, Gunung Mulu National Park, Bako National Park, Kubah National Park, and Niah National Park. Moreover, the results also showed that entertainment and tourism activities were not significantly related to the revisit intentions of the visitors, thereby rejecting hypothesis 2 . These findings contradict the findings of scholars (e.g.: Harun et al., 2018; Wu, Li, \& Li, 2018), who emphasised entertainment and tourism activities that generate unforgettable tourist destination experiences and help to reinforce their revisiting intentions. A potential reason may be due to the high costs needed for activities like labour-power in developing a safety protocol in the creation of ecotourism (Markus, Perovic, Pekovic, \& Popovic, 2019). In addition, interviewed international tourists gave a potential explanation that could be linked to the risk of growing environmental assets and residents' efficiency in the tourism destination. Results from statistical analyses showed that the tourism infrastructure was not substantially linked to the purpose of revisiting, so hypothesis 4 was not backed. Interestingly, this finding is inconsistent with previous studies that suggested that tourism infrastructure is a key feature for attracting tourists to revisit a tourism destination (Moreira \& lao, 2014; \& Nunkoo \& Seetanah, 2018) The incidence of this unexpected outcome may be due to the weak park facilities in the present case. Low infrastructure efficiency (e.g.: park and transportation facilities) decreases the intentions of tourists to visit again (Harun et al., 2018). Based on the interview at Gunung Mulu National Park, local and foreign tourists perceived tourism infrastructure was not being effectively implemented due to lack of investment and knowledge.

\section{Conclusion}

In conclusion, revisiting tourist intentions depends heavily on its price and value (Yan et al., 2015; Long \& Nguyen, 2018). In general, both local and international tourists visit protected natural areas, or ecotourism destinations for short breaks from challenging working environments. For ecotourism destinations, therefore, it is necessary to ensure that the destination image (functional characteristics) is at decent quality in order to enhance the revisiting intentions of tourists and to improve their competitive market position (Rajesh, 2013; George, 2017). From now on, the present study revealed and verified that tourists viewed the price and value as the key determinant of their ecotourism destination revisiting intentions. Subsequently, tourists are often attracted to ecotourism destinations with good value for money, which leads tourists to view the price and value factor as a determinant of their intention to visit again. 
INTERNATIONAL JOURNAL OF ACADEMIC RESEARCH IN BUSINESS AND SOCIAL SCIENCES Vol. 10, No. 9, 2020, E-ISSN: 2222-6990 @ 2020 HRMARS

\section{Implications of the Study}

\section{Theoretical Implications}

The results from the present study provides to the growing body on identification of factors contributing to tourists' revisit intentions to ecotourism destinations. In addition, the present study aims to further understand the effect of destination image factors (functional characteristics) on the revisit intentions of tourists towards ecotourism destinations, both local and international tourists.

\section{Practical Implications}

In the assurance of successful growth in ecotourism destinations, these results can be useful for local planners, business operators and policy makers. In today's competitive tourism industry, the value of the destination image has increased, especially in the context of ecotourism. The critical impacts of an ecotourism destination depend deeply on the price and value. Hence, the competitive stance and sustainability of the ecotourism destination are informed by a range of photos of destinations. Consequently, it is strongly suggested to further examine the destination image (e.g., psychological characteristics) and revisit purpose.

\section{Acknowledgement}

The funding for this project was made possible through the research grant obtained from Sarawak Multimedia Authority and Universiti Malaysia Sarawak.

\section{References}

Ajzen, I. (1991). The theory of planned behavior. Organizational Behavior and Human Decision Processes, 50(2), 179-211.

Ajzen, I. (2002). Perceived behavioral control, self-efficacy, locus of control, and the theory of planned behavior. Journal of Applied Social Psychology, 32(4), 665-683.

Anup, K. C. (2016). Ecotourism and its role in sustainable development of Nepal. INTECH Open Science, 31-59.

Bagozzi, R. P., Yi, Y., \& Phillips, L. W. (1991). Assessing construct validity in organizational research. Administrative Science Quarterly, 36(3), 421-458.

Baniya, R., Ghimire, S., \& Phuyal, S. (2017). Push and pull factors and their effects on international tourists' revisit intention to Nepal. The Gaze: Journal of Tourism and Hospitality, 8(1), 20-39.

Bock, G. W., Zmud, R. W., Kim, Y. G., \& Lee, J. N. (2005). Behavioral intention formation in knowledge sharing: Examining the roles of extrinsic motivators, social-psychological forces, and organizational climate. MIS Quarterly, 29(1), 87-111.

Bonn, M. A., Cho, M., Lee, J. J., \& Kim, J. H. (2016). A multilevel analysis of the effects of wine destination attributes on travel constraints and revisit intention. International Journal of Contemporary Hospitality Management, 28(1), 2399-2421.

Boujbel, L., \& d'Astous, A. (2015). Exploring the feelings and thoughts that accompany the experience of consumption desires. Psychology \& Marketing, 32(2), 219-231.

Center for Responsible Travel, CERST. (2017). The case for responsible travel: Trends and statistic 2017. Retrieved from https://www.responsibletravel.org/docs/Th\%20Case\%20for\%20Responsible \%20Travel\%202017_Final.pdf 
INTERNATIONAL JOURNAL OF ACADEMIC RESEARCH IN BUSINESS AND SOCIAL SCIENCES

Vol. 10, No. 9, 2020, E-ISSN: 2222-6990 @ 2020 HRMARS

Center for Responsible Travel, CERST. (2018). The case for responsible travel: Trends and statistic 2018. Retrieved from

https://www.responsibletravel.org/docs/The_Case_for_Responsible_Travel_ 2018_FINAL_FOR_WEB.pdf

Chang, L-I. (2013). Influencing factors on creative tourists' revisiting intentions: The Roles of motivation, experience and perceived value (All Dissertation, Paper 1084).

Chen, C. F., \& Chen, F. S. (2010). Experience quality, perceived value, satisfaction and behavioral intentions for heritage tourists. Tourism Management, 31(1), 29-35.

Chi, C. G. Q., \& Qu, H. (2008). Examining the structural relationship of destination image, tourist satisfaction and destination loyalty: An integrated approach. Tourism Management, 29(4), 624-636.

Chin, C. H., Law, F. Y., Lo, M. C., \& Ramayah, T. (2018). The impact of accessibility quality and accommodation quality on tourists' satisfaction and revisit intention to rural tourism destination in Sarawak: The moderating role of local communities' attitude. Global Business and Management Research, 10(2), 115-127.

Chin, W. W. (2010). How to write up and report PLS analyses. In Handbook of partial least squares (pp. 655-690). Springer, Berlin, Heidelberg.

Chiutsi, S., Mukoroverwa, M., Karigambe, P., \& Mudzengi, B. K. (2011). The theory and practice of ecotourism in Southern Africa. Journal of Hospitality Management and Tourism, 2(2), 14-21.

Choo, H., Ahn, K., \& Petrick, J. F. (2016). An integrated model of festival revisit intentions. Theory of planned behavior and festival quality/satisfaction. International Journal of Contemporary Hospitality Management, 28(4), 818-838.

Cohen, J. (1988). Statistical power analysis for the behavioral sciences. Hillsdale, NJ: Lawrence Erlbaum.

Cohen, S. A., Prayag, G., \& Moital, M. (2014). Consumer behaviour in tourism: Concepts, influences and opportunities. Current Issues in Tourism, 17(10), 872-909.

Coria, J., \& Calfucura, E. (2012). Ecotourism and the development of indigenous communities: The good, the bad, and the ugly. Ecological Economics, 73(1), 47-55.

Cronbach, L. J. (1951). Coefficient alpha and the internal structure of tests. Psychometrika, 16(3), $297-$ 334.

Crouch, G. I. \& Ritchie, J. R. B. (1999). Tourism, competitiveness, and societal prosperity. Journal of Business Research, 44(3), 137-152.

Cui, X., Lee, G., Lee, S. J., \& Kim, T. T. (2019). Structural relationships among antecedents to perceived value of ecotourism for Sichuan giant pandas in China. Sustainability, 11(1), 210-216.

Añaña, de. S. E., Anjos, D. F. A., \& Pereira, de L. M. (2018). Touristic destination image in light of the service dominant logic of marketing. Tourism \& Management Studies, 14(3), 7-18.

Dean, D., Suhartanto, D., \& Kusdibyo, L. (2019). Predicting destination image in creative tourism: A comparative between tourists and residents. International Journal of Applied Business Research, 1(1), 1-15.

Dwyer, L., \& Kim, C. (2003). Destination competitiveness: Determinants and indicators. Current Issues in Tourism, 6(5), 369-414.

Eagles, P. F. J. (2002). Trends in park tourism: economics, finance and management. Journal of Sustainable Tourism, 10(2), 132-153. 
INTERNATIONAL JOURNAL OF ACADEMIC RESEARCH IN BUSINESS AND SOCIAL SCIENCES

Vol. 10, No. 9, 2020, E-ISSN: 2222-6990 @ 2020 HRMARS

Echtner, C. M., \& Ritchie, J. B. (1991). The meaning and measurement of destination image. Journal of Tourism Studies, 2(2), 2-12.

Echtner, C. M., \& Ritchie, J. R. B. (2003). The meaning and measurement of destination image. The Journal of Tourism Studies, 14(1), 37-48.

Echtner, C. M., \& Ritchie, J. B. (1993). The measurement of destination image: An empirical assessment. Journal of Travel Research, 31(4), 3-13.

Forbes. (2017). Why millennials are the most important consumer generation for the travel industry. Retrieved from https://www.forbes.com/sites/jefffrom2/17/11/08/why-millennials-are-themost-important-consumer-generation-for-the-travel-industry $\$ 5725 \mathrm{~b} 740 \mathrm{e} 1 \mathrm{fl}$

Fornell, C., \& Larcker, D. F. (1981). Evaluating structural equation models with unobservable variables and measurement error. Journal of Marketing Research, 18(1), 39-50.

George, B. P. (2017). The evolution of destination branding: A review of branding literature in tourism. Journal of Tourism, Heritage \& Services Marketing, 3(1), 9-17.

Grytsiuk, M. Y., \& HGryciuk, Y. (2017). Building a sustainable tourism development strategy in the Carpathian region of Ukraine. BazTech, 27(1), 130-136.

Hair, J. F., Hult, G. T. M., Ringle, C. M., \& Sarstedt, M. (2017). A primer on partial least squares structural equation modeling (PLS-SEM) (2nd ed.). Thousand Oaks, CA: Sage.

Harun, A., Obong, A., Kassim, A. W. M., \& Lily, J. (2018). The effects of destination image and perceived risk on revisit intention: A study in the South Eastern Coast of Sabah, Malaysia. Ereview of Tourism Research, 15(6), 540-559.

Hernández-Lobato, L., Solis-Radilla, M. M., Moliner-Tena, M. A., \& Sánchez-García, J. (2006). Tourism destination image, satisfaction and loyalty: a study in Ixtapa-Zihuatanejo, Mexico. Tourism Geographies, 8(4), 343-358.

Huang, Y.-C., Chang, L. L., \& Backman, K. F. (2018). Detecting common method bias in predicting creative tourists' behavioural intention with an illustration of theory of planned behaviour. Current Issues in Tourism, 22(3), 307-329.

Isaac, R. K., \& Eid, T. A. (2018). Tourists' destination image: An exploratory study of alternative tourism in Palestine. Current Issues in Tourism, 22(12), 1499-1522.

Islam, S., Hossain, M. K., \& Noor, M. E. (2017). Determining drivers of destination attractiveness: The case of nature-based tourism of Bangladesh. International Journal of Marketing Studies, 9(3), 10-23.

Japutra, A., Loureiro, S. M. C., Molinillo, S., \& Ekinci, Y. (2019). Travellers' mindsets and theory of planned behaviour. Tourism Management Perspectives, 30, 193-196.

Jovanović, S., \& Ilić, I. (2016). Infrastructure as important determinant of tourism development in the countries of Southeast Europe. Ecoforum Journal, 5(1), 288-294.

Jung, D.-S. (2015). A discovery of the positive travel experience in pre-trip, on-site and post trip stage. 2015 ttra Annual International Conference, Portland, US, June 15-17.

Karim, K., Setarnawat, S., \& Viriyasuebphong, P. (2019). A Study on motivational factors of travellers to revisit Kuakata Sea Beach, Patuakhali, Bagladesh. Burapha Journal of Business Management Burapha University, 8(1), 117-133.

Khuong, M. N., \& Nguyen, P. A. (2017). Factors affecting tourist destination satisfaction and return intention- A study in Ho Chi Minh City, Vietnam. Journal of Economics, Business and Management, 5(2), 95-102. 
INTERNATIONAL JOURNAL OF ACADEMIC RESEARCH IN BUSINESS AND SOCIAL SCIENCES Vol. 10, No. 9, 2020, E-ISSN: 2222-6990 @ 2020 HRMARS

Kim, K., Hallab, Z., \& Kim, J. N. (2012). The moderating effect of travel experience in a destination on the relationship between the destination image and the intention to revisit. Journal of Hospitality Marketing \& Management, 21(5), 486-505.

Kim, W. G., Ng, C. Y. N., \& Kim, Y. S. (2009). Influence of institutional DINESERV on customer satisfaction, return intention, and word-of-mouth. International Journal of Hospitality Management, 28(1), 10-17.

Kock, N. (2017). WarpPLS user manual: Version 6.0. Laredo, TX: ScriptWarp Systems.

Lane, B. (2009). Rural tourism: An overview. The SAGE Handbook of Tourism Studies, 354-370.

Lee, J.-S., Hsu, L.-T. (Jane), Han, H., \& Kim, Y. (2010). Understanding how consumers view green hotels: How a hotel's green image can influence behavioural intentions. Journal of Sustainable Tourism, 18(7), 901-914.

Lee, S. S. (2004). College student's perception and preference of brand name foodservice in university dining operations. Unpublished Master's Thesis. Oklahoma State University, Stillwater, Oklahoma, United States.

Lertputtarak, S. (2012). The relationship between destination image, food image, and revisiting Pattaya, Thailand. International Journal of Business and Management,7(5), 111-121.

Li, M., Cai, L. A., Lehto, X. Y., \& Huang, J. (2010). A missing link in understanding revisit intention-The role of motivation and image. Journal of Travel \& Tourism Marketing, 27(4), 335-348.

Liu, C. H. S., \& Lee, T. (2016). Service quality and price perception of service: Influence on word-ofmouth and revisit intention. Journal of Air Transport Management, 52(1), 42-54.

Lo, M. C., Songan, P., Mohamad, A. A., \& Yeo, A. W. (2013). Rural tourism and destination image: Community perception in tourism planning. The Macro-theme Review, 2(1), 102-118.

Loi, L. T. I., So, A. S. I., Lo, I. S., \& Fong, L. H. N. (2017). Does the quality of tourist shuttles influence revisit intention through destination image and satisfaction? The case of Macao. Journal of Hospitality and Tourism Management, 32(1), 115-123.

Long, N., \& Nguyen, T. L. (2018). Sustainable development of rural tourism in an Giang Province, Vietnam. Sustainability, 10(4), 953-973.

Lopes, S. D. F. (2011). Destination image: Origins, developments and implications. PASOS. Revista de Turismo y Patrimonio Cultural, 9(2), 305-315.

Luo, J. M., \& Lam, C. F. (2017). Entertainment tourism. Routledge.

Mandić, A., Mrnjavac, Ž., \& Kordić, L. (2018). Tourism infrastructure, recreational facilities and tourism development. Tourism and Hospitality Management, 24(1), 41-62.

Markus, Z., Perovic, D., Pekovic, S., \& Popovic, S. (2019). Assessing tourist revisit intention through the sports and recreational services offered. Business Systems Research Journal: International Journal of the Society for Advancing Business \& Information Technology (BIT), 10(2), 141-150.

Mazilu, M., \& Stancioiu, F. (2009). Tourist destination competitiveness: Between desirable and imperative. Geography Series, 12, 176-188.

Mo, C., Howard, D. R., \& Havitz, M. E. (1993). Testing an international tourist role typoloty. Annals of Tourism Research, 20(2), 319-335.

Mohamad, M., \& Ab Ghani, N. I. (2014). Comparing destination image and loyalty between first-time and repeat-visit tourists. In SHS Web of Conferences (Vol. 12, p. 01047). EDP Sciences.

Mondino, E., \& Beery, T. (2019). Ecotourism as a learning tool for sustainable development. The case of Monviso Transboundary Biosphere Reserve, Italy. Journal of Ecotourism, 18(2), 107-121. 
INTERNATIONAL JOURNAL OF ACADEMIC RESEARCH IN BUSINESS AND SOCIAL SCIENCES

Vol. 10, No. 9, 2020, E-ISSN: 2222-6990 @ 2020 HRMARS

Moreira, P., \& lao, C. A. (2014). Longitudinal study on the factors of destination image, destination attraction and destination loyalty. Journal of Social Sciences, 3(3), 90-112.

Moric, I. (2013). Clusters as a factor of rural tourism competitiveness: Montenegro experiences. Business Systems Research Journal, 4(2), 94-107.

Murphy, P., Pritchard, M. P., \& Smith, B. (2000). The destination product and its impact on traveller perceptions. Tourism Management, 21(1), 43-52.

Ngoc, K. M., \& Trinh, N. T. (2015). Factors affecting tourists' return intention towards Vung Tau City, Vietnam - A mediation analysis of destination satisfaction. Journal Advancement Management Science, 3(4), 292-298.

Nianyong, H., \& Zhuge, R. (2001). Ecotourism in China's nature reserves: Opportunities and challenges. Journal of Sustainable Tourism, 9(3), 228-242.

Nunally, J., \& Bernstein, L. (1994). Psychometric Theory. New York: MacGrow-Hill Higher.

Nunkoo, R., \& Seetanah, B. (2018). Foreign direct investment and tourism development: A theoretical and empirical review. Sage Handbook of Tourism Management, 45-57.

Packer, J., Ritchie, B., \& Ballantyne, R. (2011). Travel experiences of Chinese visitors to Australia. Paper presented at the China Tourism Research Symposium, Brisbane.

Petrick, J. F. (2004). The roles of quality, value and satisfaction in predicting cruise passengers' behavioral intentions. Journal of Travel Research, 42(4), 397-407.

$\mathrm{Qu}, \mathrm{H}$. (1997). Determinant factors and choice intention for Chinese restaurant dining: A multivariate approach. Journal of Restaurant and Foodservice Marketing 2(2), 35-49.

Qu, H., Kim, L. H., \& Im, H. H. (2011). A model of destination branding: Integrating the concepts of the branding and destination image. Tourism Management, 32(3), 465-476.

Rajesh, R. (2013). Impact of tourist perceptions, destination image and tourist satisfaction on destination loyalty: a conceptual model. PASOS. Revista de Turismo y Patrimonio Cultural, 11(3), 67-78.

Sadat, M. M., \& Chang, L.-H. (2016). The impact of environmental quality of revisiting intention. Journal of Quality Assurance in Hospitality \& Tourism, 17(2), 209-223.

Sarkar, A. (2014). Brand love in emerging market: A qualitative investigation. Qualitative Market Research: An International Journal, 17(4), 481-494.

Sekaran, U., \& Bougie, R. (2013). Research methods for business: A skill building approach paperback (6th ed.). West Sussex, UK: John Wiley \& Sons.

Shen, Y. S. (2016). Perceived value in tourism experience. Travel and Tourism Research Association: Advancing Tourism Research Globally. In 2016 TTRA International Conference (pp. 1-12). Amherst, United States.

Som, A. \& Badarneh, M. (2011). Tourist satisfaction and repeat visitation: Toward a new comprehensive model. International Journal of Human and Social Sciences, 6(1), 38-45.

Stylidis, D., Shani, A., \& Belhassen, Y. (2017). Testing an integrated destination image model across residents and tourists. Tourism Management, 58(1), 184-195.

Su, M. M. \& Wall, G. (2009). The Qing-Tibet railway and Tibetan tourism: Travelers perspectives. Tourism Management, 30(5), 650-657.

Tasci, A. D. A., \& Gartner, W. C. (2007). Destination image and its functional relationships. Journal of Travel Research, 45(4), 413-425. 
INTERNATIONAL JOURNAL OF ACADEMIC RESEARCH IN BUSINESS AND SOCIAL SCIENCES

Vol. 10, No. 9, 2020, E-ISSN: 2222-6990 @ 2020 HRMARS

Tourism Malaysia. (2019). FAQ - Visit Malaysia 2020. Retrieved from https://www.tourism. gov.my/pdf/uploads/VM2020_faq.pdf?fbclid=IwAR2LEkJmcITrRrdmrinpOqbo6YfVIVLkd1ge_ ttco5XFKQ6EJvJONiCA

Trung, N. V. H., \& Khalifa, G. S. (2019). Impact of destination image factors on revisit intention of hotel's international tourists in Ba Ria-Vung Tau (BR-VT) the mediating role of positive word of mouth. International Journal on Recent Trends in Business and Tourism, 3(2), 106-115.

Vesci, M., \& Botti, A. (2019). Festival quality, theory of planned behavior and revisiting intention: Evidence from local and small Italian culinary festivals. Journal of Hospitality and Tourism Management, 38(1), 5-15.

Whang, H., Yong, S., \& Ko, E. (2016). Pop culture, destination images, and visit intentions: Theory and research on travel motivations of Chinese and Russian tourists. Journal of Business Research, 69(2), 631-641.

Wu, H. C., Li, M. Y., \& Li, T. (2018). A study of experiential quality, experiential value, experiential satisfaction, theme park image, and revisit intention. Journal of Hospitality \& Tourism Research, 42(1), 26-73.

Xu, H., Cui, Q., Ballantyne, R., \& Packer, J. (2013). Effective environmental interpretation at Chinese natural attractions: The need for an aesthetic approach. Journal of Sustainable Tourism, 21(1), 117-133.

Yan, X., Wang, J., \& Chau, M. (2015). Customer revisit intention to restaurants: Evidence from online reviews. Information Systems Frontiers, 17(3), 645-657.

Yelkur, R. (2000). Customer satisfaction and the services marketing mix. Journal of Professional Services Marketing, 21(1), 105-115.

Zhang, H., Wu, Y., \& Buhalis, D. (2018). A model of perceived image, memorable tourism experiences and revisit intention. Journal of Destination Marketing \& Management, 8(1), 326-336.

Zikmund, W. G., Babin, B. J., Carr, J. C., \& Griffin, M. (2010). Business research methods (8 ${ }^{\text {th }}$ ed.). United States: South-Western Cengage Learning. 